\title{
Moss Flora of Kanneliya Forest Reserve, Sri Lanka
}

\author{
N. C. S. Ruklani ${ }^{1,2}$ and S. C. K. Rubasinghe ${ }^{2^{*}}$ \\ ${ }^{1}$ Postgraduate Institute of Science, University of Peradeniya, Peradeniya, Sri Lanka. \\ ${ }^{2}$ Department of Botany, Faculty of Science, University of Peradeniya, Peradeniya, Sri Lanka. \\ Accepted June 22, 2015
}

\begin{abstract}
Bryophytes; liverworts, mosses and hornworts, comprise an important yet poorly researched group of plants in Sri Lanka. Varied climate and topography of the island provide ample habitat diversity for bryophytes. However, the diversity and species richness of the three morphological groups of bryophytes within the country are yet to be discovered. Kanneliya Forest Reserve, a prominent lowland rain forest in the wet zone of Sri Lanka has been a base for much scientific research on both flora and fauna. However, the bryophyte flora within the forest, apart from a few old collections remains unexplored. The present study was undertaken to explore the moss flora of the Kanneliya Forest Reserve and serves as the first taxonomic study on mosses in the forest. Mosses were collected from different habitats of the forest, along with the substrate. They were stored in paper packets labeled with the locality details. Collected samples were observed for their morphological and anatomical characters, using dissecting, light and stereo microscopes. Specimens were identified to their generic/specific level using taxonomic keys, monographs and other available literature. A total of 68 specimens of mosses were collected from different habitats within the forest and 45 specimens were identified to their generic and/or specific level. The moss flora of the Kanneliya Forest Reserve represented 13 families and 21 genera of mosses. Taxonomic descriptions with the characteristic features were prepared for the identified species of mosses. Herbarium specimens prepared for each identified species are deposited at the Department of Botany, University of Peradeniya.
\end{abstract}

Keywords: Bryophytes, diversity, morphology, taxonomy, tropical forests

\section{INTRODUCTION}

Bryophytes, the non-vascular embryophytes comprise three morphological groups; liverworts, mosses and hornworts in three Phyla, Marchantiophyta (liverworts), Bryophyta (mosses) and Anthocerotophyta (hornworts).The groups share a common unique life cycle among land plants with a dominant gametophytic generations in the life cycle (Shaw and Renzaglia, 2004; Crandall-Stotler et al., 2007; Shaw et al., 2011). Bryophytes occupy an important position in almost all the ecosystems, performing valuable ecological services. They hold a key position in the land plant evolution as the first plant group that successfully colonize land (Kenrick and Crane, 1997; Nickrent et al., 2000; Wellman et al., 2003; Qiu et al., 2006; Rubasinghe, 2011; Ruklani and Rubasinghe, 2013).

Sri Lankan mosses: Phylum Bryophyta or the mosses comprises of about 1300 species worldwide (Goffinet et al., 2009). Mosses in the tropics are highly diverse and usually confined to the tropical rainforests (Richards, 1984; Frahm and Gradstein, 1991) mainly because bryophytes prefer moist environments, and these wet tropical rain forests are a perfect habitat. Sri Lanka is a tropical island and exhibits a significant diversity of bryophytes that it had attracted a number of botanists, bryologists and explorers as a hot spot for their collections and studies. The island consists of a considerable coverage of forests, which provide numerous habitats with favorable microclimatic conditions like ideal temperature, humidity, $\mathrm{pH}$ and light for bryophytes. Sri Lanka records a forest cover of about $20 \%$ today facilitating the growth of these tiny plants (Erdelen, 1996) and recorded as one of the species rich countries for bryophytes (Geffert et al., 2013). Explorations on Sri Lankan bryophytes began in the $19^{\text {th }}$ Century and many contributions to the field made mainly by British bryologists and explorers such as G. Gardner (1812 - 1849), G. H. K. Thwaites (1812 - 1882), W. Mitten (1819 - 1906) and C. C. Townsend (Rubasinghe and Long, 2014). Most of these collectors have focused the Central highlands of Sri Lanka for moss collections (O'Shea, 2003; Rubasinghe and Long, 2014). Much of the existing collections of mosses are scattered in herbaria in other countries; Berlin, London, Bogor, Brussels, Paris, Stockholm, Tokyo, Vienna and remain inaccessible to Sri Lankan scientists. All major publications on Sri Lankan mosses up to date are based on the collections made mainly by Gardner

*Corresponding author's email: srubasinghe@pdn.ac.lk 
and Thwaites and few sporadic collections made afterwards. The existing lists of mosses are limited (Abeywickrama and Jansen, 1978; O'Shea, 2003). According to the most recent checklist of mosses by O'Shea (2002), 174 genera and 569 species of mosses are recorded in Sri Lanka, and a literature based study recorded a high endemicity (11\%) of mosses from the country (O'Shea, 2003).

However, apart from a few sporadic collections, no proper explorations or systematic studies on Sri Lankan mosses have been carried out. Available literature on Sri Lankan bryoflora does not provide sufficient information on habitat details or phenological information to track the changes of species diversity or species distribution. This highlights the importance of systematic field explorations and subsequent taxonomic identification and documentation of bryophytes of the country. As part of a study to evaluate the bryophyte diversity in the country, this taxonomic survey of mosses was carried out at the Kanneliya Forest Reserve. The main objective of the present study was to explore the moss flora of the Kanneliya Forest Reserve; an under-explored area for bryophytes.
Kanneliya Forest Reserve: Kanneliya $\left(6^{\circ} 15^{\prime}\right.$ $\left.18.4998^{\prime \prime} / \mathrm{N}, 80^{\circ} 22^{\prime} 24.2898^{\prime \prime} / \mathrm{E}\right)$ is a prominent, unique lowland rain forest in the wet zone of Sri Lanka with an average annual rainfall of $>$ $2500 \mathrm{~mm}$ distributed throughout the year without a dry spell (Amarasinghe et al., 1994; Bandaratillake, 2003; Neckaris and Jayawardene, 2004). It is located in the Galle District in the Southern Province (Fig. 1) and is the largest of the Kanneliya-Dediyagala-Nakiyadeniya forest complex (Bopage et al., 2011). The forest covers a total land area of $53.11 \mathrm{~km}^{2}$ (Nekaris and Jayewardene, 2004). It remained a virgin forest until the felling by the Ceylon Plywood Corporation from 1968 to 1988 (Pethiyagoda, 1994; Singhakumbura, 1995). The forest coverage of Kanneliya has also decreased due to tea plantations followed by population increase (Lindstrom et al., 2012). The forest is gifted with a magnificent biodiversity harboring $78 \%$ of plant species endemic to Sri Lanka including nationally $(25.7 \%)$ and globally $(46.5 \%)$ threatened plant species (Singhakumbura, 1995; Ekaratne et al., 2003). This speaks as to why it is very important to explore such biodiversity hot spots to investigate their floristic component and implement conservation measures.
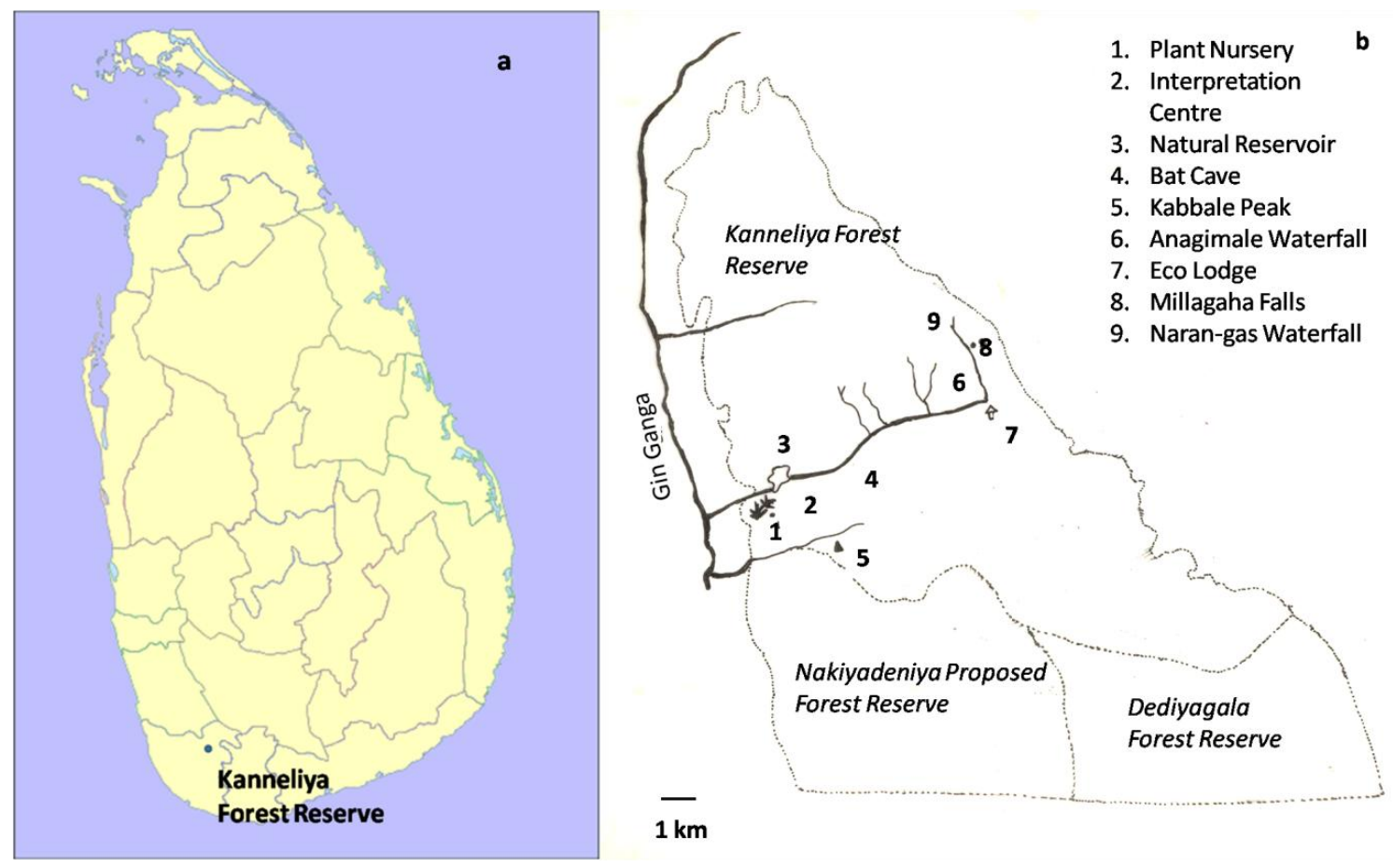

Figure 1. (a) Map of Sri Lanka showing the location of Kanneliya Forest Reserve (b) Detailed map of Kanneliya Forest Reserve Area (Adopted from http://www.traveljournals.net) 
Many surveys and scientific investigations in Kanneliya forests have been focused on both flora and fauna (Walker, 1957; Pethiyagoda, 1994; Brown et al., 2003; Nekaris and Jayawardene, 2004; Gamage et al., 2006; Pethiyagoda, 2009). But there are no taxonomic explorations on bryophytes except for a few old records of sporadic collections (Onraedt, 1986; Herzog, 1911). Although conservation aspects for the survival of native biodiversity has been evaluated for Kanneliya Forest Reserve, no such measures have been implemented on bryophytes, mainly due to the lack of taxonomic or floristic information of the group (Gunatilleke and Gunatilleke, 1990; Gunatilleke and Gunatilleke, 1991; Bandaratilleke, 2003; Guantillake and Gunatilleke, 2005). It is very important not only to explore the bryophyte flora within the forest but also to investigate the microhabitat diversity that harbors these plants and emphasize the importance of conserving these reservoirs.

\section{MATERIALS AND METHODS \\ Sampling}

Fresh samples of mosses including vegetative and reproductive structures were collected during monsoonal and inter-monsoonal periods of the year. Specimens were collected along with the substrate so that their rhizoids and vegetative propagules were not damaged. When sporophytes were present, care was taken not to damage the calyptrae and opercula which can be easily detached from the capsules. The colour, texture and other delicate characters (e.g. odour, length, and width) were recorded. Digital photographs of habitats and habit characters were obtained during collections. Samples were stored in paper packets prepared according to Schofield's (1985) method. Each herbarium packet was labeled with; collection number, collection date, locality, habit and habitat details, GPS coordinates and collectors' names.

\section{Identification and recording of data}

Both macroscopic and microscopic characters of the gametophyte and sporophyte were observed using hand lens, dissecting (Hertel \& Reus-Optik Kassel), light (Eruomex, Arnhem, Holland) and stereomicroscopes (Olympus CX21). Leaf and stem anatomical sections were prepared using glycerin where necessary. Photographs of microscopic characteristics were taken using a Nikon D3200 camera and an accus-scope (Model 3025-BE-CS). Important characteristics were recorded for each specimen collected. Collected specimens were then identified to generic or specified level using latest taxonomic keys, descriptions and manuals. Classification was based on the latest classification systems for mosses by Goffinet et al., (2009).

\section{RESULTS AND DISCUSSION}

A total of 68 mosses were collected from different habitats and substrates within the Kanneliya Forest Reserve (Table 1). They represented 13 families and 21 genera of mosses. Forty-five mosses were identified to their generic and/or specific level (Table 2).

Kanneliya Forest reserve is a magnificent habitat provider for a variety of mosses. Among these epiphytic mosses were the most common within the forest. This is a common phenomenon for tropical rain forests and is mainly to obtain adequate light and moisture since the forest ground remain dark covered by leaf litter (Webb, 1959; Chantanaorrapint, 2010; Valente et al., 2013).

The moss families, Pterobryaceae, Calymperaceae, Meteoriaceae and Sematophyllaceae have found to be common in tropical rain forests (Acebay et al., 2003; Gradstein and Pócs, 1989). These families were encountered with high generic and species numbers during the present study. Among these families, Calymperaceae (Fig. 2), Hypnaceae and Sematophyllaceae were found to be dominant in terms of generic and species diversity within the Kanneliya forest.

Table 1. Habitat diversity of mosses within the Kanneliya Forest Reserve

\begin{tabular}{lc}
\hline \multicolumn{1}{c}{ Habitat } & Number of taxa of mosses \\
\hline Soil & 09 \\
On tree trunks (epiphytic) & 30 \\
On leaves (epiphyllous) & 0 \\
On wet rock (epilythic) & 27 \\
Other (on walls) & 2 \\
\hline
\end{tabular}


Table 2. List of mosses found in the Kanneliya Forest Reserve

\begin{tabular}{|c|c|c|}
\hline Family & Genera & Species \\
\hline Bryaceae & Bryum & Bryum sp. \\
\hline \multirow[t]{5}{*}{ Calymperaceae } & Calymperes & Calymperes sp. \\
\hline & Leucophanes & Leucophanes glaucum (Schwägr.) Mitt. \\
\hline & Mitthyridium & Mitthyridium repens (Harv.) H. Rob. \\
\hline & & Mitthyridium fasciculatum Hook. \& Grev. H. Rob. \\
\hline & Syrrhopodon & Syrrhopodon gardneri (Hook.) Schwägr. \\
\hline Dicranaceae & Leucoloma & Leucoloma amoene-virens Mitt. \\
\hline Fissidentaceae & Fissidens & Fissidens serratus Müll. Hal. \\
\hline Hookeriaceae & Hookeria & Hookeria acutifolia Hooker \& Greville \\
\hline \multirow[t]{3}{*}{ Hypnaceae } & Ectropothecium & Ectropothecium sp. \\
\hline & Hypnum & Hypnum cupressiforme Hedw. \\
\hline & Pseudotaxiphyllum & Pseudotaxiphyllum distichaceum (Mitt.) Z. Iwats. \\
\hline \multirow[t]{2}{*}{ Leucobryaceae } & Campylopus & Campylopus sp. \\
\hline & Leucobryum & Leucobryum bowringii Mitt. \\
\hline Meteoriaceae & Aerobryidium & Aerobryidium filamentosum (Hook.) M. Fleisch. \\
\hline Neckeraceae & Homaliodendron & Homaliodendron javanicum (Müll.Hal.) M. Fleisch. \\
\hline Polytrichaceae & Pogonatum & Pogonatum marginatum Mitt. \\
\hline Pterobryaceae & Pterobryopsis & Pterobryopsis sp. \\
\hline Pylaisiadelphaceae & Taxithelium & Taxithelium sp. \\
\hline \multirow[t]{3}{*}{ Sematophyllaceae } & Papillidiopsis & Papillidiopsis sp. \\
\hline & Sematophyllum & Sematophyllum sp. \\
\hline & Trichosteleum & Trichosteleum boschii (Dozy \& Molk.) A. Jaeger \\
\hline
\end{tabular}

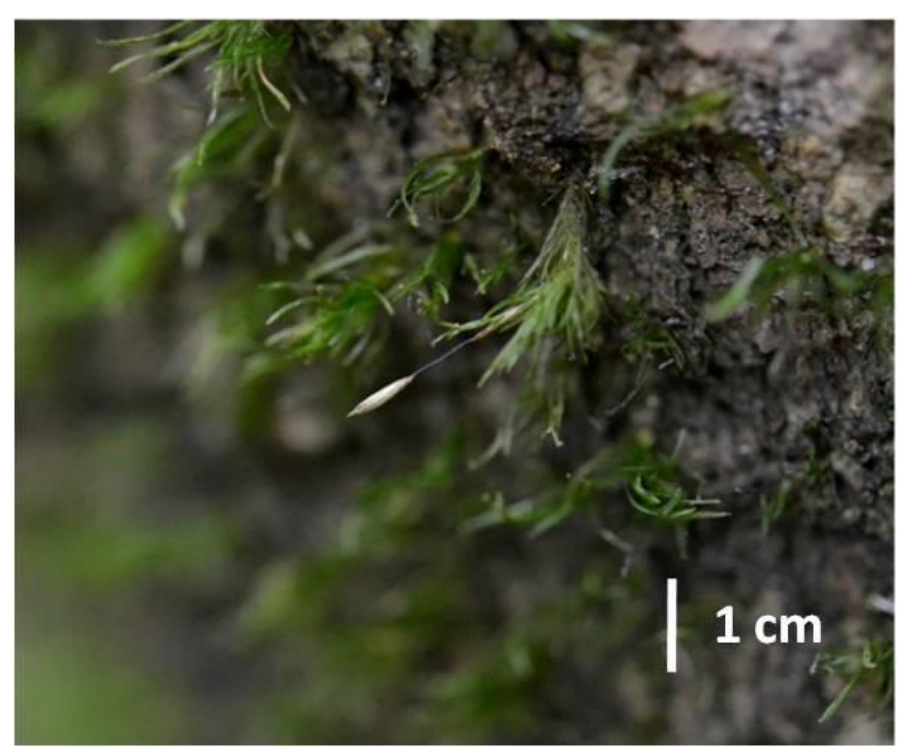

Figure 2. An epiphytic Calymperes species with a persistent calyptrae; an exclusive character for the identification of members of the Family Calymperaceae 
Identified species are described with a brief taxonomic description as follows.

\section{Family Calymperaceae}

Leucophanes glaucum (Schwägr.) Mitt. Journal of the Proceedings of the Linnean Society, Botany, Supplement 1:25. 1859.

Plants small, $0.5-1.5 \mathrm{~cm}$ high, whitish green, in dense tufts. Stem simple and poorly branched. Leaves $0.3 \mathrm{~mm}-5.0 \mathrm{~mm}$ long, narrowly lanceolate (Fig. 3A), costa spinose or papillose ventrally. Cells in the leaf margin hyaline. Costal leucocysts in 3-4 layers near leaf base. Chlorocysts in cross section quadrangular. Gemmae common at the leaf
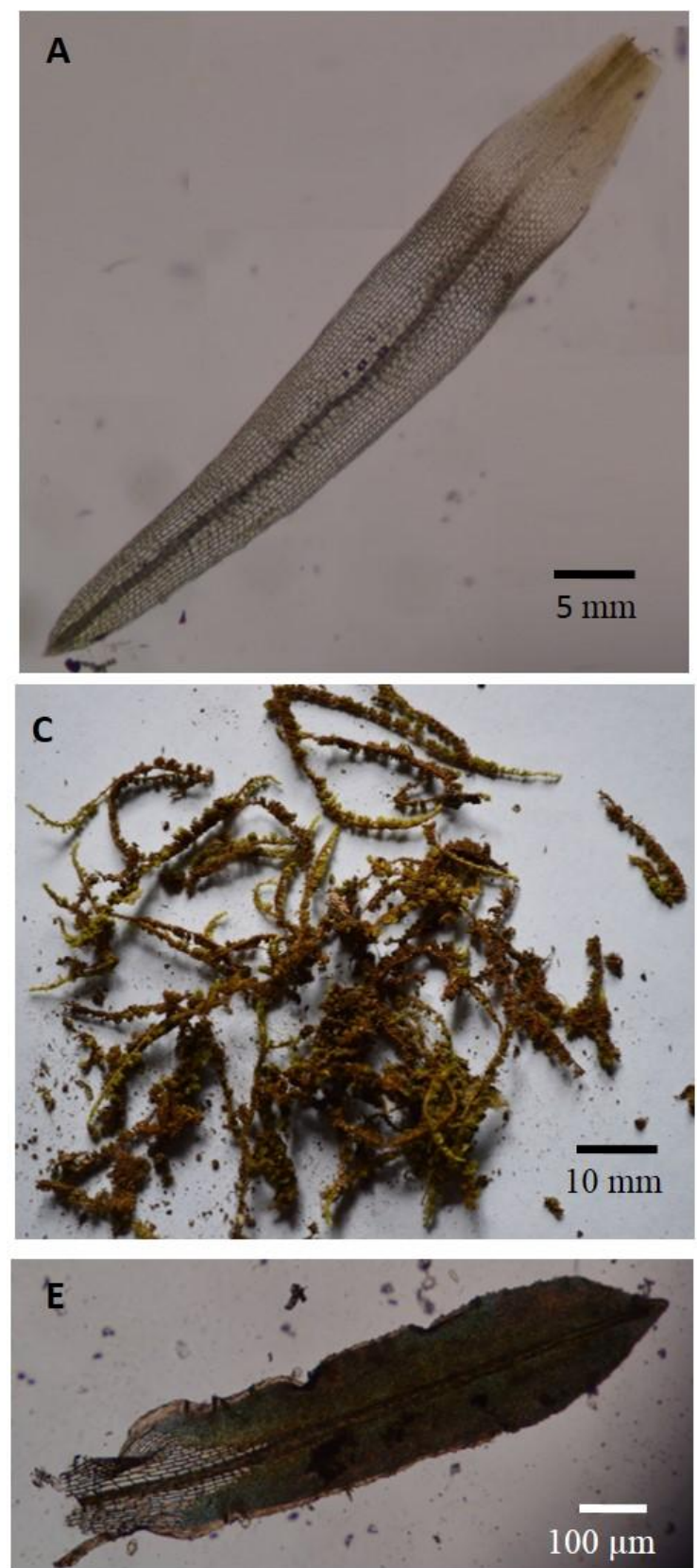

apex (Fig. 3B). Sporophytes not seen.

Mitthyridium repens (Harv.) H. Rob. Phytologia 32: 434. 1975.

Plants small, yellowish green forming less compact mats (Fig 3C) with short branches. Stem creeping. Leaves oblong and very short $(<2 \mathrm{~mm})$ (Fig. 3E), contorted and crispate when dry. Cells of lamina rounded, chlorophyllose and papillose. Small size, broad boarder bearing sharp, spreading teeth (Fig. 3D) are distinct characters. Gemmae sparse, green in colour on both sides of the leaf apex (Fig. 3F).
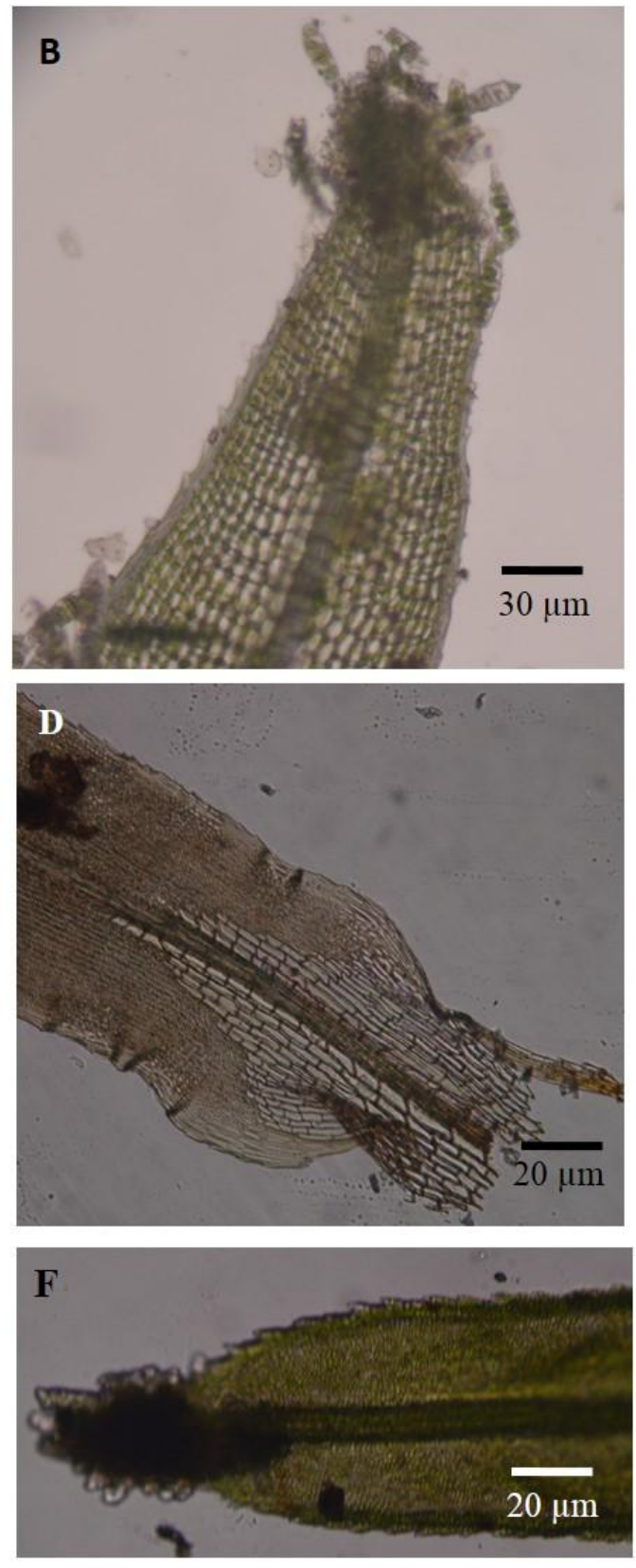

Figure 3. (A) Leaf of Leucophanes glaucum, (B) Green colour gemmae at the leaf apex of L. glaucum, (C) Habit of Mitthyridium repens, (D) Serrulate boarder of leaves, (E) Leaf of M. repens, (F) Gemmae at the leaf apex 
Mitthyridium fasciculatum Hook. \& Grev.H. Rob. Phytologia 32: 433. 1975.

Plants small to medium sized, $5 \mathrm{~mm}-10 \mathrm{~mm}$ high, dull green in colur. Stem elongates and sloped, branching occurs at the slopes. Leaves $0.5 \mathrm{~mm}$ $0.9 \mathrm{~mm}$ long, ecostate, broad-lanceolate, contorted when dry, undulate, broad and serrulate margined. Cells thick walled and isodiametric. Gemmae adaxial on the apex of costa.

Syrrhopodon gardneri (Hook.) Schwägr. Species Muscorum Frondosorum, Supplementum Secundum 2: 110. pl. 131. 1824.

Plants medium sized, $8 \mathrm{~mm}-10 \mathrm{~mm}$ high, stems evident, short, and whitish. Rhizoids dark red in colour. Leaves $0.6-1 \mathrm{~mm}$ long, sharply dentate or serrate at the shoulders. Cells of upper lamina rectangular. Cancellinae distinct. Elongate and hyaline marginal cells absent or present in part only at the base. Gemmae frequent, on adaxial tip of costa.

\section{Family Dicranaceae}

Leucoloma amoene-virens Mitt. Journal of the Proceedings of the Linnean Society, Botany, Supplement 1: 13. 1859.

Plants yellowish green, $2-3 \mathrm{~cm}$ tall. Leaves $2-4 \mathrm{~mm}$ long, curled when dry, falcate when wet, long acuminate, lanceolate, serrulate at the apex, margined with a hyaline boarder (Fig. 4B, C) Cells linear or linear rhomboid, inner laminal cells rounded to quadrangular, forming short bands parallel to the narrow costa (Fig. 4A).

\section{Family Fissidentaceae}

Fissidens serratus Müll. Hal. Botanische Zeitung (Berlin) 5: 804. 1847.

Plants small, 1.0-2.5 mm high, light green or yellowish green. Stems very short, appearing stemless. Leaves $0.5-1 \mathrm{~mm}$ long, imbricate, lanceolate. Leaf blade coarsely serrate. Costa thick and excurrent. Cells of the lamina irregularly quadrate to hexagonal. Marginal cells not differing from inner cells.

\section{Family Hookeriaceae}

Hookeria acutifolia Hooker \& Greville, Edinburgh J. Sci. 2: 225. 1825.

Plants creeping in patches. Stems green, with a central strand. Leaves $2.0-3.0 \mathrm{~mm}$ long, ovate shaped, apex acute with entire margins. Costa absent. Laminal cells hexagonal. Capsules blackish brown, oblong to elliptic, calyptra conicmitrate.

\section{Family Hypnaceae}

Hypnum cupressiforme Hedw. Species

Muscorum Frondosorum 291. 1801.

Plants small to medium sized, $2.0-8 \mathrm{~cm}$ long, golden green, sub-pinnately branched. Stem brownish with a poorly developed central strand. Shoots tinged with brown colour in older parts.Leaves 1-2 mm long, secund, ovatelanceolate with subulate apices. Costa absent. Cells of the lamina short and wide.

Pseudotaxiphyllum distichaceum (Mitt.) Z. Iwats. Journal of the Hattori Botanical Laboratory 63: 449. 1987.

Plants yellowish green glossy. Stems prostrate, irregularly branched. Leaves distant, spreading with acute, serrate- dentate apices, obolonglanceolate to ovate-lanceolate. Leaf cells linear, smooth or papillose adaxially.

\section{Family Leucobryaceae}

Leucobryum bowringii Mitt. Journal of the Proceedings of the Linnean Society, Botany, Supplement 1: 26. 1859.

Small to medium sized plants, $1-2.5 \mathrm{~cm}$ high, grayish green, lustrous. Leaves lanceolate, spreading when wet contorted when dry, with an elliptical base, subulate and acute apex, acumina smooth dorsally. Laminal cells rectangular to linear. In cross section leucocysts in 1-2 layers on both sides of quadrangular chlorocysts.

\section{Family Meteoriaceae}

Aerobryidium filamentosum (Hook.) M. Fleisch. Die Natürlichen Pflanzenfamilien I (3): 821. 1906.

Plants hanging, shoots up to $10 \mathrm{~cm}$ long, light green in colour. Branches complanate. Leaves 2-3 mm long, short acuminate, highly concave, entire margined.Costa absent. Laminal cells rhomboidal to lineal, mamillose.

\section{Family Neckeraceae}

Homaliodendron javanicum (Müll. Hal.) M. Fleisch. Hedwigia 45: 74. 1906.

Plants with a creeping stem and erect shoots up to 3-5 cm long (Fig. 4D). Slightly dendroid. Leaves 1-2 mm long, oval-lingulate, with a costa running more than $3 / 4$ of the leaf length (Fig. 4E). Apical cells isodiametric.

\section{Family Polytrichaceae}

Pogonatum marginatum Mitt. in J. Proc. Linn. Soc., Bot., Suppl. 1: 153 (1859).

Plants 25-38 $\mathrm{mm}$ tall, with leaves arranged into three rows, two lateral rows and one ventral row. Stem Leaves oblong and serrate (Fig. 4F). Lamellae absent (Fig. 4G). Leaf lamina unistratose with irregular shaped cells (Fig. 4H) and leaf margin bistratose. Leaf base extended. 

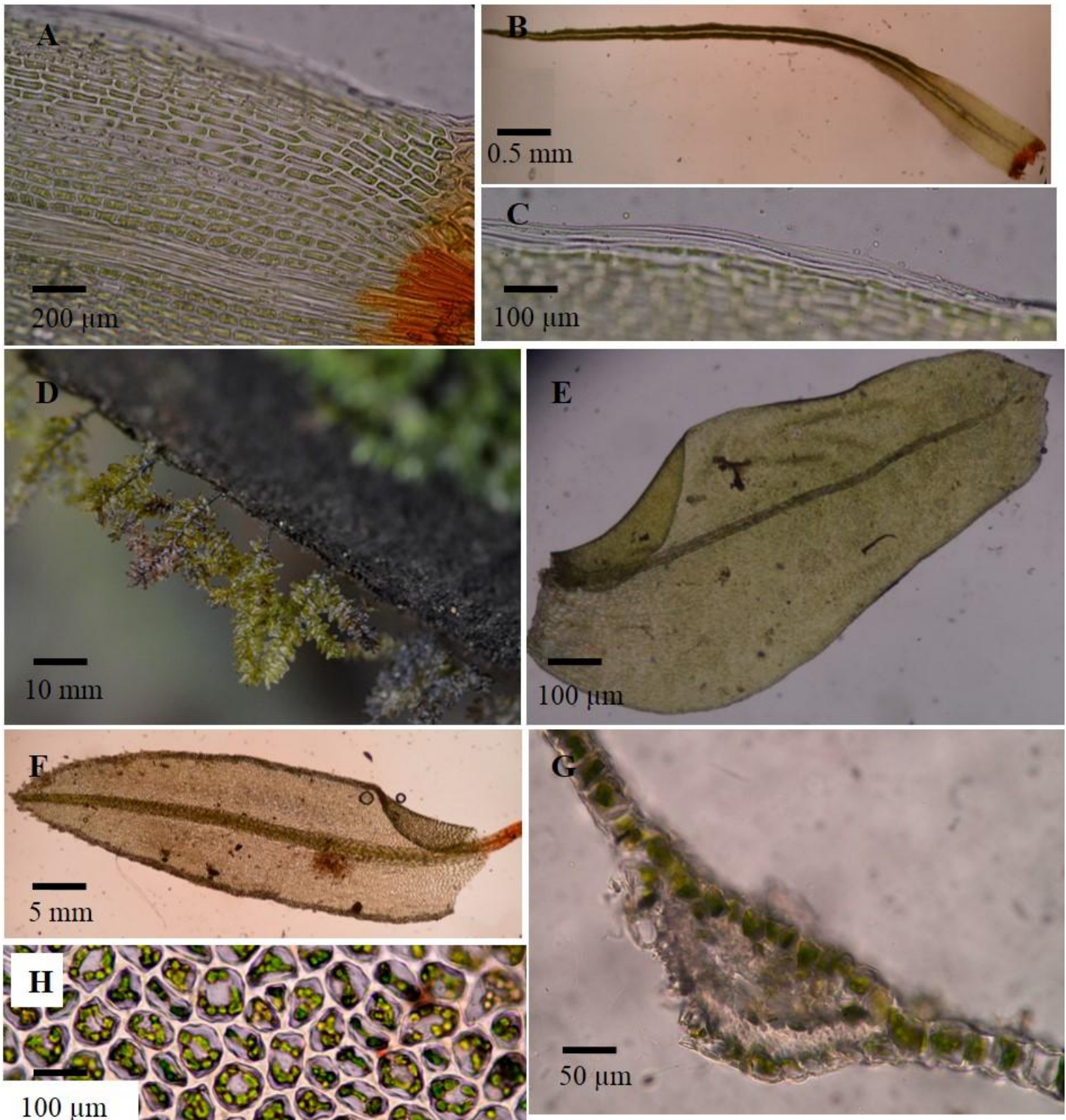

$100 \mu \mathrm{m}$

Figure 4. (A) Cells of the Leucoloma amoene-virens leaf, (B) Leaf with a long acuminate apex, (C) Hyaline boarder of the leaf, (D) Habit of Homaliodendron javanicum growing on a tree trunk, (E) Leaf of H. javanicum with an oblong shape, (F) Leaf of Pogonatum marginatum, (G) Cross section of leaf of P. marginatum (H) Irregular cells of laminal cells of $P$. marginatum

\section{Family Sematophyllaceae}

Trichosteleum boschii (Dozy \& Molk.) A. Jaeger Bericht über die Thätigkeit der St. Gallischen Naturwissenschaftlichen Gesellschaft 1876-77: 421 (Gen. Sp. Musc. 2: 487). 1878.

Plants small, 5-8mm long, yellowish green slightly glossy, in loose tufts. Stem dark reddish brown. Branching sparse and regular. Leaves 0.5-1.5 mm long, ovate- lanceolate, concave, ecostate, margins weakly serrate or serrulate in the upper half. Leaf laminal cells linear to rhomboid, unipapillose.

Publications on Sri Lankan mosses by Onraedt
(1986) and Herzog (1911) have included Leucoloma amoene-virens, L. herzogii, Octoblepherum albidum, Leucophanes glaucescens, Leucophanes octoblepharoides, Calymperes contractum, C. fordii, C. nietneri, Mitthyridium fasciculatum, M. repens, Syrrhopodon caespitosus, S. muelleri, Symphysodontella involuta, Acoroporium asperifolium, Rhapidostichum ramulinum, Trichosteleum boschii, T. monostichum, $T$. pseudomammosum, Ectropothecium laevigatum, Pogonatum marginatum and Atrichum pallidum as mosses collected from Kanneliya. However, the 
exact localities, substrate details or taxonomic descriptions of these mosses are not mentioned in these citations.

Kanneliya Forest Reserve presents a complex ecosystem with numerous habitats, including fresh water aquatic systems, mountainous and rocky environments. Lush growth of mosses were observed under rock crevices, bark of trees, and rotting wood. Bryophytes lack a proper cuticle and are highly sensitive to micro-climatic conditions; minute changes to these habitats can have detrimental effect on these plants. Therefore, a thorough knowledge on species present and their vulnerable habitats is essential to initiate conservation measures on these important plants.

\section{CONCLUSION}

The present study serves as the first taxonomic survey focusing on the moss flora of a tropical lowland rain forest in Sri Lanka. According to the present taxonomic survey, the moss flora of Kanneliya Forest Reserve comprised of 13 families and 21 genera. A herbarium collection of the mosses collected is maintained at the Department of Botany, University of Peradeniya.

\section{ACKNOWLEDGMENTS}

The authors wish to acknowledge the University of Peradeniya Research Grant (URG/2013/13/S) for funding this research. We extend our thanks to Ms. Prabha Rupasinghe for helping us in the field.

\section{REFERENCES}

Abeywickrama, B.A. and Jansen, M.A.B. (1978). A check list of the mosses of Sri Lanka. UNESCO: Man and the Biosphere National Committee for Sri Lanka 2: 1-25.

Acebey, A., Gradstein, S. R., and Krömer, T. (2003). Species richness and habitat diversification of bryophytes in submontane rain forest and fallows of Bolivia. Journal of Tropical Ecology 19(1): 9-18.

Amarasinghe, L. D., Hominick, W. M., Briscoe, B. R., and Reid, A. P. (1994). Occurrence anddistribution of entomopathogenic nematodes in Sri Lanka. Journal of Helminthology 68(04): 277-286.

Bandaratillake, H. M. (2003). Community Participation. In The Management In The Kanneliya-Dediyagala-Nakiyadeniya Proposed Biosphere Reserve. Journal of the National Science Foundation of Sri Lanka
31(1-2): 139-145.

Bopage, M. M., Wewalwala, K., Krvavac, M., Jovanovic, O., Safarek, G. and Pushpamal, V. (2011). Species diversity and threat status of amphibians in the Kanneliya Forest, lowland Sri Lanka. Salamandra 47(3): 173-177.

Brown, W. A., Udagama-Randeniya, P. V., and Seneviratne, S. S. (2003). Two new species of chiggers (Acari: Leeuwenhoekiidae and Trombiculidae) from bats (Chiroptera) collected in the Kanneliya Forest Reserve of Sri Lanka.International Journal of Acarology 29(1): 69-73.

Chantanaorrapint, S. (2010). Ecological studies of epiphytic Bryophytes along altitudinal gardients in Southern Thailand (Doctoral dissertation, Universität Bonn).

Crandall-Stotler, B. J., and Sharon E. Bartholomew-Began. (2007). Morphology of mosses (phylum Bryophyta). Flora of North America north of Mexico (FNA) 27: 3-13.

Erdelen, W. (1996). Tropical rain forests in Sri Lanka: characteristics, history of human impact, and the protected area system. In: D.S. Edwards, W.E. Booth, and S.C. Choy (eds.). Tropical Rainforest Research - Current Issues. Proceedings of the Conference held in Bandar Seri Begawan, April 1993. Kluwer Academic Publishers: 503-511.

Ekaratne, K., Fernando, R. H. S. S., de Silva, S., Bambaradeniya, C.N.B., and de Silva, D. (2003).A comparison of the Conservation and Legal Status of the Fauna and Flora of Sri Lanka. IUCN Sri Lanka, Colombo.

Frahm, J. P., and Gradstein, S. R. (1991). An altitudinal zonation of tropical rain forests using byrophytes. Journal of Biogeography: 669-678.

Gamage, D. T., de Silva, M. P., Inomata, N., Yamazaki, T., and Szmidt, A. E. (2006). Comprehensive molecular phylogeny of the sub-family Dipterocarpoideae (Dipterocarpaceae) based on chloroplast DNA sequences. Genes and Genetics Systems 81(1): $1-12$.

Geffert, J. L., Frahm, J. P., Barthlott, W., and Mutke, J. (2013). Global moss diversity: spatial and taxonomic patterns of species richness. Journal of Bryology 35(1): 1-11.

Goffinet, B., Buck, W. R. and Shaw, A. J. (2009). Morphology, anatomy, and classification of the Bryophyta. In: B. Goffinet and A. J. Shaw (eds.). Bryophyte Biology. 2nd edition. Cambridge University Press.

Gradstein, S. R. and Po'cs, T. (1989). Bryophytes. Pp. 311-325 in Lieth, H. and Werger, M. J. A. (eds). Tropical rain forest ecosystems. Ecosystems of the World Vol. 14B. Elsevier, Amsterdam.

Gunatilleke, I. A. U. N., and Gunatilleke, C. V. S. 
(1990). Distribution of floristic richness and its conservation in Sri Lanka. Conservation Biology 4(1): 21-31.

Gunatilleke, I. A. U. N., and Gunatilleke, C. V. S. (1991). Threatened woody endemics of the wet lowlands of Sri Lanka and their conservation. Biological conservation 55(1): 17-36.

Gunatilleke, I. A. U. N., Gunatilleke, C. V. S., and Dilhan, M. A. A. B. (2005). Plant biogeography and conservation of the south-western hill forests of Sri Lanka. Contributions to Biodiversity Exploration and Research in Sri Lanka. The Raffles Bulletin of Zoology Supplement 12: 9-22.

Herzog, T. (1911). Beitrage zur LaubMoosflora von Ceylon. Hedwigia 50: 115-145.

Kenrick, P., and Crane, P. R. (1997). The origin and early evolution of plants on land. Nature 389(6646): 33-39.

Lindström, S., Mattsson, E., and Nissanka, S. P. (2012). Forest covers change in Sri Lanka: The role of small scale farmers. Applied Geography 34: 680-692.

Nekaris, K. A. I., and Jayewardene, J. (2004). Survey of the slender loris (Primates, Lorisidae Gray, 1821: Loris tardigradus Linnaeus, 1758 and Loris lydekkerianus cabrera, 1908 in Sri Lanka. Journal of Zoology 262(4): 327-338.

Nickrent, D. L., Parkinson, C. L., Palmer, J. D., and Duff, R. J. (2000). Multigene phylogeny of land plants with special reference to bryophytes and the earliest land plants. Molecular Biology and Evolution 17(12): 1885-1895.

Onraedt, M. (1986). Bryophytes de Sri Lanka. IX. Mousses récoltées à Sri Lanka. Bulletin $d u$ Jardin botanique national de Belgique/Bulletin van de Nationale Plantentuin van Belgie 56: 453-482.

O'Shea, B. (2002). Checklist of the mosses of Sri Lanka. Journal of Hattori Botanical Laboratory 92: 125-164.

O'Shea B. J. (2003). Bryogeographical relationships of the mosses of Sri Lanka. Journal of the Hattori Botanical Laboratories 93: 293 - 304.

Pethiyagoda, R. (1994). Threats to the indigenous freshwater fishes of Sri Lanka and remarks on their conservation. Hydrobiologia 285(1-3): 189-201.

Pethyagoda, R. (2009). Two new species of shrub frogs (Rhacophoridae: Philautus) from the lowlands of Sri Lanka. Zootaxa 2122: 51-68.
Qiu, Y. L., Li, L., Wang, B., Chen, Z., Knoop, V., Groth-Malonek, M., and Davis, C. C. (2006). The deepest divergences in land plants inferred from phylogenomic evidence. Proceedings of the National Academy of Sciences 103(42): 15511-15516.

Richards, W. P. (1984). The ecology of tropical forest bryophytes. In: Schuster, R.M. (Ed.), New Manual of Bryology. Hattori Botanical Laboratory, Japan: 1233-1270.

Rubasinghe, S. C. K. (2011). Phylogeny and taxonomy of the complex thalloid liverwort family Cleveaceae Cavers. PhD Thesis, University of Edinburgh, Edinburgh.

Rubasinghe, S. C. K, and Long, D. G. (2014). Bryophytes of Sri Lanka: a review of past exploration and taxonomic research and priorities for the future. Journal of Bryology 36(4): 259-270.

Ruklani, N. C.K., and Rubasinghe, S. C. K. (2013). A Preliminary Survey of Bryophytes in the Central Province, Ceylon Journal of Science (Bio. Sci.) 42(1): 67-72.

Schofield, W. B. (1985). Introduction to Bryology. Macmillan, New York.

Shaw, A. J., Szövényi, P., and Shaw, B. (2011). Bryophyte diversity and evolution: windows into the early evolution of land plants. American Journal of Botany. 98(3): 352-369.

Shaw, J., and Renzaglia, K. (2004). Phylogeny and diversification of bryophytes. American Journal of Botany 91(10): 1557-1581.

Singhakumara, B. M. P. (1995). Ecological assessment of Kanneliya, DediyagalaNakiyadeniya (KDN) Forest Complex. Department of Forestry and Environmental Science, University of Sri Jayewardenepura, Nugegoda.

Valente, E. D. B., Pôrto, K. C., Bastos, C. J. P., and Ballejos-Loyola, J. (2013). Diversity and distribution of the bryophyte flora in montane forests in the Chapada Diamantina region of Brazil. Acta Botanica Brasilica 27(3): 506518.

Walker, T. G. (1957). Idiopteris: a new genus of ferns from Ceylon. Kew Bulletin 12(3): 429432.

Webb, L. J. (1959). A physiognomic classification of Australian rain forests. The Journal of Ecology 47(3): 551-570.

Wellman, C. H., Osterloff, P. L. and Mohiuddin, U. (2003). Fragments of the earliest land plants. Nature. 425 (6955): 282-285. 